\title{
INITIAL HEIGHT AND NITROGEN FERTILIZATION ON DEFERRED SIGNALGRASS
}

\author{
ALTURA INICIAL E ADUBAÇÃO NITROGENADA EM PASTOS DIFERIDOS DE \\ CAPIM-BRAQUIÁRIA
}

\section{Arejacy Antônio Sobral SILVA ${ }^{\mathbf{1}}$; Dilermando Miranda da FONSECA ${ }^{2}$; Manoel Eduardo Rozalino SANTOS ${ }^{3}$; Bráulio Maia de Lana SOUSA ${ }^{4}$; Virgílio Mesquita GOMES ${ }^{5}$; Reinaldo Bertola CANTARUTTI ${ }^{6}$}

1. Professor do Instituto Federal de São Paulo, Avaré, SP, Brasil. arejacy.silva@ifsp.edu.br ; 2. Professor do Departamento de Zootecnia da Universidade Federal de Viçosa - UFV, Viçosa, MG, Brasil; 3. Professor da Faculdade de Medicina Veterinária da Universidade Federal de Uberlândia - UFU, Uberlândia, MG, Brasil; 4. Professor da Universidade Federal de Sergipe - UFS, São Cristóvão, SE, Brasil; 5. Professor do Departamento de Zootecnia da Universidade Estadual de Minas Gerais - UFMG, Montes Claros, MG, Brasil; 6. Professor do Departamento de Solos - UFV, Viçosa, MG, Brasil.

\begin{abstract}
Thus study was conducted with the objective of evaluating production and forage characteristics of Signalgrass (Brachiaria decumbens cv. Basilisk) deferred at different initial heights and nitrogen doses. Three initial sward heights (low $-10 \mathrm{~cm}$, medium $-20 \mathrm{~cm}$ and high $-30 \mathrm{~cm}$ ), three nitrogen doses $(40,80$ and $120 \mathrm{~kg} / \mathrm{ha})$ and a control treatment, of no fertilization were evaluated. The experimental design utilized was of completely randomized blocks with three replications, in a subdivided-plot arrangement. There was no interaction between sward initial height and nitrogen dose for the variables analyzed. The Signalgrass deferred at an elevated initial height presented greater masses of forage, live stem, dead stem and dead leaves; higher percentage of dead stem and falling rate; and lower number of vegetative tillers, percentage of live leaves and live leaf/live stem ratio. Elevation in the nitrogen dose increase along with the number of live and vegetative tillers; masses of forage, live stem, dead stem, dead leaves and live leaves; percentage of live stem; and live tissue/dead tissue ratio; and reduced the percentage of dead leaves and the live leaf/live stem ratio. Signalgrass can be deferred at low and medium initial heights and varied nitrogen doses, according to the objectives and possibilities of the farmer.
\end{abstract}

KEYWORDS: Brachiaria decumbens. Production seasonality. Sward structure. Tillering.

\section{INTRODUCTION}

Deferment is the management strategy in which a certain area of the pasture is excluded from grazing from the end of the summer or the beginning of fall, enabling accumulation of forage mass to be utilized at the time of scarcity (winter). For being a simple management strategy and usually of lower production cost, once the forage harvesting is performed by the animal itself, it is considered a technique of easy application.

Historically, deferred pastures have been associated with the presence of elevated forage mass with low nutritional value. To circumvent this hindrance, management strategies such as nitrogen fertilization and reduction of pasture height at the beginning of the deferment period can be adopted, aiming to stimulate the appearance of younger tillers on the pasture and thus improve its nutritional value (FONSECA; SANTOS, 2009).

The strategic use of nitrogen fertilization in the beginning of pasture deferment can increase forage production and stimulate tillering, provided that the deferment period is not excessively long
(SANTOS et al., 2009a). By increasing population, nitrogen fertilization enables the deferment to be done in smaller areas and for reduced periods, allowing utilization of the pasture by herds for a longer time during the summer and the fall (SANTOS et al., 2009b).

Higher pasture height at the beginning of the deferment period can result in greater forage production; however, such condition is usually associated with lower pasture efficiency, because of the possibility of lodging of larger plants (FONSECA; SANTOS, 2009). On the other hand, the lowering of the pasture in the period close to the beginning of deferment enables greater incidence of light at the bottom of plants, which can stimulate the appearance of young tillers and, in fact, result in deferred pasture of better nutritional values in the off-season months.

Thus, the understanding of the effects of nitrogen fertilization and of sward height at the beginning of the deferment period can support recommendations of management under deferred pasture conditions. Therefore, this study was carried out to determine the dose(s) of nitrogen and the 
initial height(s) of the Signalgrass (Brachiaria decumbens cv. Basilisk Stapf.) sward which result in adequate forage mass and structure of the pasture deferred in the beginning of the winter.

\section{MATERIAL AND METHODS}

The experiment was conducted in the period from March 10 to June 05, 2010, with a duration of 118 days, in an area of the Forage Sector of the Department of Animal Science of Universidade Federal de Viçosa, in Viçosa, MG, Brazil (20 $45^{\circ}$ $\mathrm{S} ; 42^{\circ}$ 51' W; $651 \mathrm{~m}$ altitude).
The climate region of Viçosa, according to the Köppen (1984) classification, is of Cwa type, with well defined dry (May to October) and rainy (November to April) seasons. The average annual precipitation is of $1,340 \mathrm{~mm}$, with average air relative humidity of $80 \%$ and annual average temperature of $19^{\circ} \mathrm{C}$. The climatic information during the experimental period was obtained at the meteorological station of Universidade Federal de Viçosa, located approximately 500 meters away from the experiment site (Table 1).

Table 1. Monthly means of minimum, average and maximum daily temperature, total monthly precipitation and total monthly evaporation from March to July 2010

\begin{tabular}{lccccc}
\hline Month & $\begin{array}{c}\text { Average } \\
\text { temperature } \\
\left({ }^{\circ} \mathrm{C}\right)\end{array}$ & $\begin{array}{c}\text { Maximum } \\
\text { temperature } \\
\left({ }^{\circ} \mathrm{C}\right)\end{array}$ & $\begin{array}{c}\text { Minimum } \\
\text { temperature } \\
\left({ }^{\circ} \mathrm{C}\right)\end{array}$ & Rainfall $(\mathrm{mm})$ & $\begin{array}{c}\text { Evaporation } \\
(\mathrm{mm})\end{array}$ \\
\hline March & 22.9 & 29.2 & 19.1 & 184.8 & 121.7 \\
April & 20.4 & 27.1 & 16.3 & 28.1 & 103.4 \\
May & 18.4 & 24.9 & 14.3 & 35.4 & 76.0 \\
June & 15.3 & 23.5 & 9.9 & 0.9 & 73.6 \\
July & 17.3 & 25.0 & 12.4 & 0.0 & 84.9 \\
\hline
\end{tabular}

A pasture of Signalgrass (Brachiaria decumbens cv. Basilisk Stapf.) established for more than ten years was utilized in this experiment. The soil of the experimental area is a Red-Yellow Latosol of clayey texture, with moderately undulating relief (EMBRAPA, 2006), and, according to the results of the chemical analysis, on the $0-20-\mathrm{cm}$ layer, it presented the following characteristics (Table 2).

Table 2. Chemical characteristics of soil samples of the $0-20 \mathrm{~cm}$ deep layer in the experimental area, in December 2009, on Forage Sector of the Department of Animal Science of Universidade Federal de Viçosa, in Viçosa, MG.

\begin{tabular}{|c|c|c|c|c|c|c|c|c|c|c|c|}
\hline Identification & $\begin{array}{c}\mathrm{pH} \\
\mathrm{H}_{2} \mathrm{O}\end{array}$ & $\begin{array}{l}\mathrm{P} \\
\mathrm{mg} /\end{array}$ & $\begin{array}{l}\mathrm{K} \\
\mathrm{Im}^{3}\end{array}$ & $\mathrm{Ca}$ & $\mathrm{Mg}$ & $\begin{array}{c}\mathrm{Al} \\
\mathrm{cmol}_{\mathrm{C}}\end{array}$ & $\mathrm{H}+\mathrm{Al}$ & ${ }^{T}$ & V & & $\begin{array}{l}\text { P-rem } \\
\mathrm{mg} / \mathrm{L}\end{array}$ \\
\hline Block 1 & 5.6 & 3.3 & 27 & 0.8 & 0.2 & 0.1 & 3.47 & 4.54 & 24 & 9 & 33.4 \\
\hline Block 2 & 5.4 & 2.9 & 17 & 0.7 & 0.2 & 0.3 & 3.47 & 4.41 & 21 & 24 & 24.7 \\
\hline Block 3 & 5.5 & 2.9 & 42 & 0.9 & 0.3 & 0.3 & 3.47 & 4.78 & 27 & 19 & 36.2 \\
\hline
\end{tabular}

Based on the results from soil analysis (Table 2), on the good condition of plants at the time when the experiment took place, there was no $\mathrm{pH}$ correction. Fertilization of phosphate and potassium, for management, was done at the beginning of the experiment with application of 50 $\mathrm{kg} / \mathrm{ha} \mathrm{P}_{2} \mathrm{O}_{5}$ and $50 \mathrm{~kg} / \mathrm{ha} \mathrm{K}_{2} \mathrm{O}$, in the form of single superphosphate and potassium chloride, on the grass top, respectively. Fertilization doses were calculated according to recommendations of Cantarutti et al. (1999).
Three sward heights (low $-10 \mathrm{~cm}$, medium $20 \mathrm{~cm}$ and high $-30 \mathrm{~cm}$ ) were evaluated at the beginning of the deferment period, randomized to the plots $(8 \times 3 \mathrm{~m})$, and three nitrogen doses $(40,80$ and $120 \mathrm{~kg} / \mathrm{ha}$ ), in addition to a control treatment, with no fertilization, randomized to the subplots, in a subdivided-plot arrangement, with three replications.

In the beginning of the deferment period $(03 / 10 / 2010)$, the Signalgrass was lowered with backpack mower at the heights desired $(10,20$ or 30 
cm). Subsequently, three nitrogen fertilization sessions were carried out, according to treatments. The source of nitrogen was ammonium sulfate; all the doses of sulfur were standardized with application of flower of sulfur. The Signalgrass remained deferred for 118 days. On the last day of deferment $(07 / 05 / 2010)$, all the evaluations of the forage plant were performed.

The measurements of plant height and extended plant were conducted at three points per experimental unit. Plant height, at every point, was determined attempting to cause the least disturbance possible in the plant community and utilizing a graduated ruler. Plant height had the distance between the horizon of the top of plants and the soil surface level as criterion. Extended plant height was measured by extending the tillers of the grass in the vertical direction, and recording the longest distance from the soil surface to the tip of the leaves. Leaf falling rate was calculated by the quotient between extended plant height and plant height (SANTOS et al., 2009c).

For the determination of forage mass and morphological components, three forage samples were collected in every experimental unit, utilizing $0.16 \mathrm{~m}^{2}$ squares allocated in representative points of the average sward height. The tillers within the frame were harvested close to the soil, with the aid of pruning shears, then conditioned in properly identified plastic bags. These samples were transported to laboratory and subdivided in two parts. One of the samples was separated manually into live leaf (live leaf blade), live stem, dead leaf (dead leaf blade) and dead stem. These components were weighed and subsequently dried in forcedventilation oven at $65^{\circ} \mathrm{C}$, for $72 \mathrm{~h}$, then weighed again. The other subsample was conditioned in paper bag, weighed and placed in forced-ventilation oven at $65^{\circ} \mathrm{C}$ for $72 \mathrm{~h}$, then weighed once more. With these data, it was possible to calculate the masses of forage and morphologic components. Morphologic components were expressed in percentage of forage mass. The ratios of masses of live leaf mass/live stem and live tissues/dead tissues were also calculated.

Tiller population density was determined within three $0.0625 \mathrm{~m}^{2}$ squares per experimental unit, allocated at representative points of the average sward height. Tillers were harvested at the soil level, conditioned in plastic bags and taken to laboratory for separation into vegetative, reproductive and dead tillers. Live tillers without visible inflorescence were named vegetative tillers; live tillers with visible inflorescence were classified as reproductive; and those which presented the stem completely necrotized were classified as dead. The sum of vegetative with reproductive tillers corresponded to live tillers.

For each trait, variance analysis was proceeded. All the dataset was tested so as to ensure that the main principles of variance analysis were met. Characteristics live leaf/live stem and falling rate had their data converted into logarithm. Since the sward height $\times$ nitrogen dose interaction was not significant for all the variables evaluated, there was comparison between the marginal means of the levels of primary factor (sward height) by the Student-Newman-Keuls' test. For the secondary factor (nitrogen dose), regression analysis was conducted, considering the models which best fit to the data. Statistical analyses were conducted at significance level of up to $5 \%$ probability of occurrence of type I error.

\section{RESULTS}

The Signalgrass presented greater plant height $(\mathrm{P}<0.05)$ when deferred at high and medium initial heights, in comparison with that deferred at low initial height. The lowest extended plant height was recorded $(\mathrm{P}<0.05)$ in the Signalgrass deferred at low height, intermediate in that deferred at medium height and the highest was found in the Signalgrass deferred at high initial height (Table 3).

Table 3. Structural characteristics of Signalgrass deferred at three initial sward heights

\begin{tabular}{lcccc}
\hline \multirow{2}{*}{ Characteristic } & \multicolumn{3}{c}{ Sward height } & CV \\
\cline { 2 - 4 } & Low & Medium & High & $(\%)$ \\
\hline Plant height $(\mathrm{cm})$ & $39.9 \mathrm{~b}$ & $53.1 \mathrm{a}$ & $52.8 \mathrm{a}$ & 9.05 \\
Extended plant height $(\mathrm{cm})$ & $46.4 \mathrm{c}$ & $65.8 \mathrm{~b}$ & $79.9 \mathrm{a}$ & 11.55 \\
Falling rate* & $1.16 \mathrm{~b}$ & $1.25 \mathrm{ab}$ & $1.55 \mathrm{a}$ & 12.89 \\
Forage mass $(\mathrm{kg} / \mathrm{ha} \mathrm{DM})$ & $6,970 \mathrm{~b}$ & $10,595 \mathrm{a}$ & $10,918 \mathrm{a}$ & 14.09 \\
Live stem mass (kg/ha DM) & $1,783 \mathrm{~b}$ & $2,424 \mathrm{a}$ & $2,468 \mathrm{a}$ & 21.08 \\
Dead blade mass (kg/ha DM) & $1,967 \mathrm{~b}$ & $3,349 \mathrm{a}$ & $3,408 \mathrm{a}$ & 17.12 \\
Dead stem mass (kg/ha DM) & $2,066 \mathrm{~b}$ & $3,406 \mathrm{a}$ & $4,093 \mathrm{a}$ & 16.67 \\
Percentage of live leaves (\%) & $16.66 \mathrm{a}$ & $12.57 \mathrm{~b}$ & $9.12 \mathrm{c}$ & 18.22 \\
Percentage of dead stems (\%) & $29.90 \mathrm{~b}$ & $32.73 \mathrm{ab}$ & $37.98 \mathrm{a}$ & 16.12
\end{tabular}


SILVA, A. A. S. et al.

\begin{tabular}{lcccc} 
Live leaf/live stem ratio* & $0.65 \mathrm{a}$ & $0.40 \mathrm{~b}$ & $0.31 \mathrm{c}$ & 19.06 \\
Number of vegetative tillers $\left(\right.$ tiller $\left./ \mathrm{m}^{2}\right)$ & $802 \mathrm{a}$ & $694 \mathrm{ab}$ & $551 \mathrm{~b}$ & 15.30 \\
Number of reproductive tillers $\left(\right.$ tiller/m $\left./ \mathrm{m}^{2}\right)$ & $74 \mathrm{~b}$ & $167 \mathrm{a}$ & $178 \mathrm{a}$ & 17.20 \\
\hline
\end{tabular}

For each characteristic, means followed by the same letter do not differ by the SNK test $(\mathrm{P}>0.05)$

* Statistical analysis conducted in transformed data (logarithm).

The greatest falling rate value was recorded $(\mathrm{P}<0.05)$ in the Signalgrass deferred at high initial height, intermediate in that deferred at medium height and the lowest in that deferred at a low height (Table 3).

The mass of live leaves was not influenced by initial sward height $(\mathrm{P}>0.05)$; its value was, on average, $1,173 \mathrm{~kg} / \mathrm{ha} \mathrm{DM}$. On the other hand, the masses of forage, live stem, dead leaf and dead stem were affected by the initial sward height $(\mathrm{P}<0.05)$; Greater values for these characteristics were recorded in the Signalgrass deferred at high and medium initial heights, in relation to that deferred at a low initial height (Table 3).

The percentages of live leaves and dead stems and the live leaf/live stem ratio were affected by the initial sward height $(\mathrm{P}<0.05)$. Overall, the elevation in the initial sward height reduced the proportion of live leaves sand the live leaf/live stem ratio; it also increased the percentage of dead stems (Table 3).

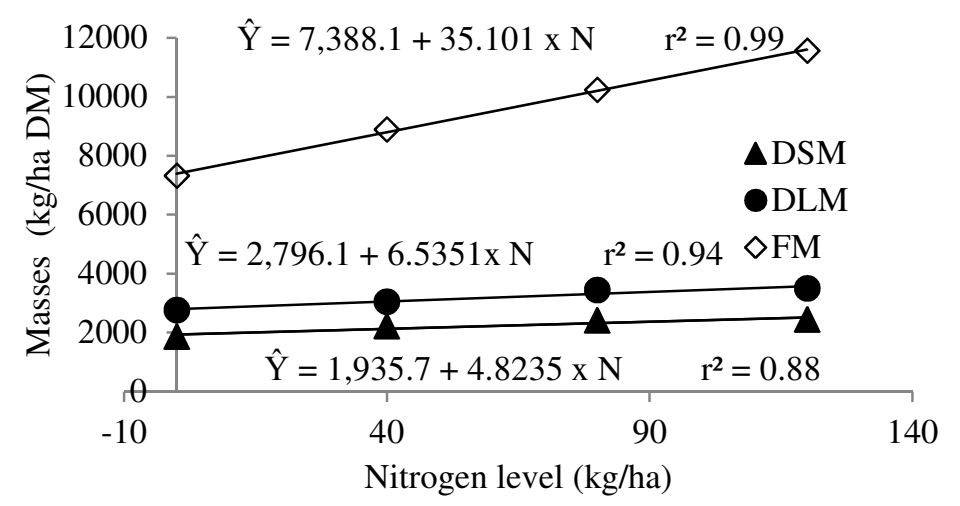

Figure 1. Masses of forage (FM), dead leaves (DLM) and dead stems (DSM) of Signalgrass deferred and fertilized with nitrogen level.

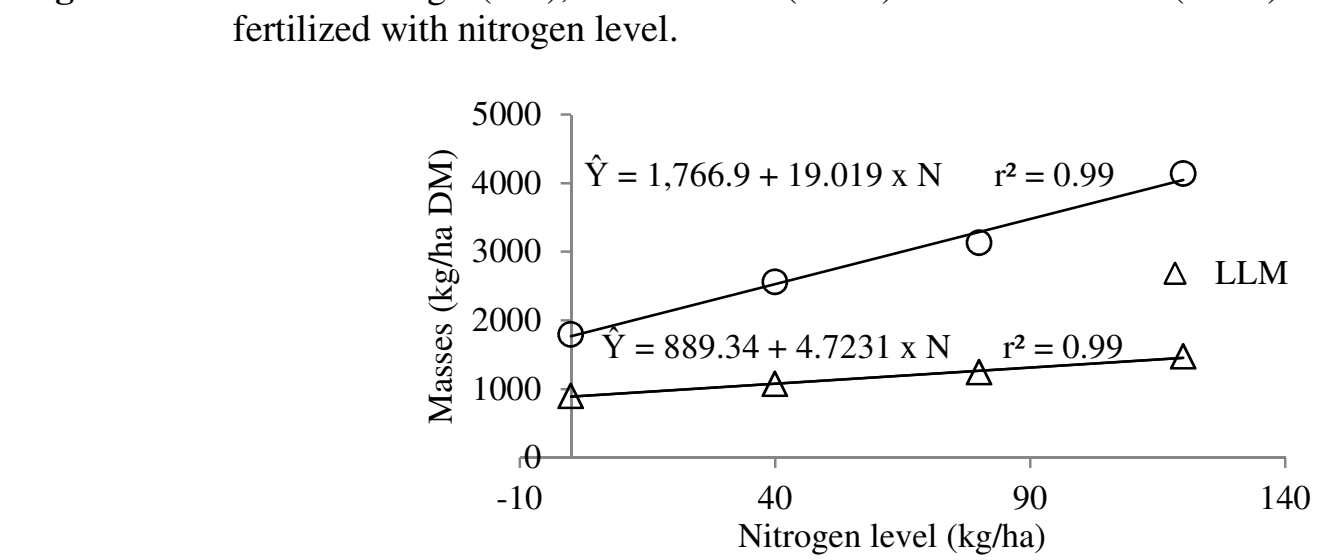

Figure 2. Masses of live leaves (LLM) and live stems (LSM) of Signalgrass deferred and fertilized with nitrogen level.
The number of dead tillers was not affected by the initial sward height $(\mathrm{P}>0.05)$, presenting, on average, 912 tiller $/ \mathrm{m}^{2}$. The number of vegetative and reproductive tillers, in turn, was influenced by the sward height at the beginning of deferment $(\mathrm{P}<0.05)$. The highest number of vegetative tillers was recorded in the Signalgrass deferred at a low initial height, intermediate in that deferred at medium height, and the lowest in that deferred at high initial height. The Signalgrass deferred at medium and high initial heights presented higher number of reproductive tillers, in relation to that deferred at a low height (Table 3 ).

Plant and extended plant heights, as well as falling rate, were not affected by the nitrogen dose $(\mathrm{P}>0.05)$. Opposite response pattern occurred with the masses of forage, live leaves, live stems, dead leaves and dead stems, which increased linearly $(\mathrm{P}<0.05)$ with elevation in the dose of nitrogen (Figures 1 and 2). 
The percentages of dead leaves and live stems varied linearly with the nitrogen dose $(\mathrm{P}<0.05)$. The elevation in the nitrogen dose increased the percentage of live stems, but reduced the percentage of dead leaves (Figure 3).

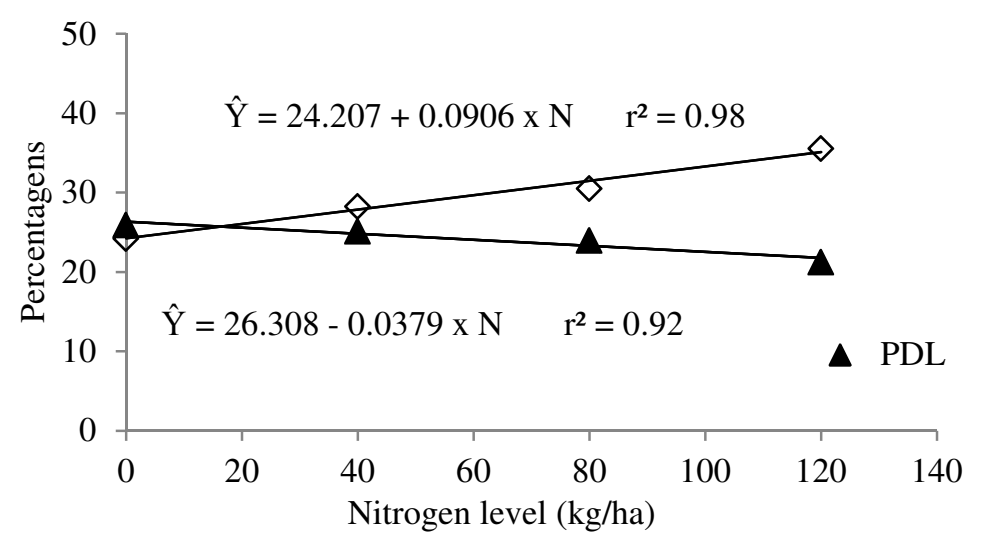

Figure 3. Percentages of dead leaves (PDL) and live stems (PLS) of Signalgrass deferred and fertilized with nitrogen level.

The ratios between the masses of live tissue/dead tissue and between the masses of live leaf/live stem were linearly affected by the nitrogen dose $(\mathrm{P}<0.05)$. The elevation in the dose of nitrogen increased the live tissue/dead tissue ratio and decreased the live leaf/live stem ratio (Figure 4).

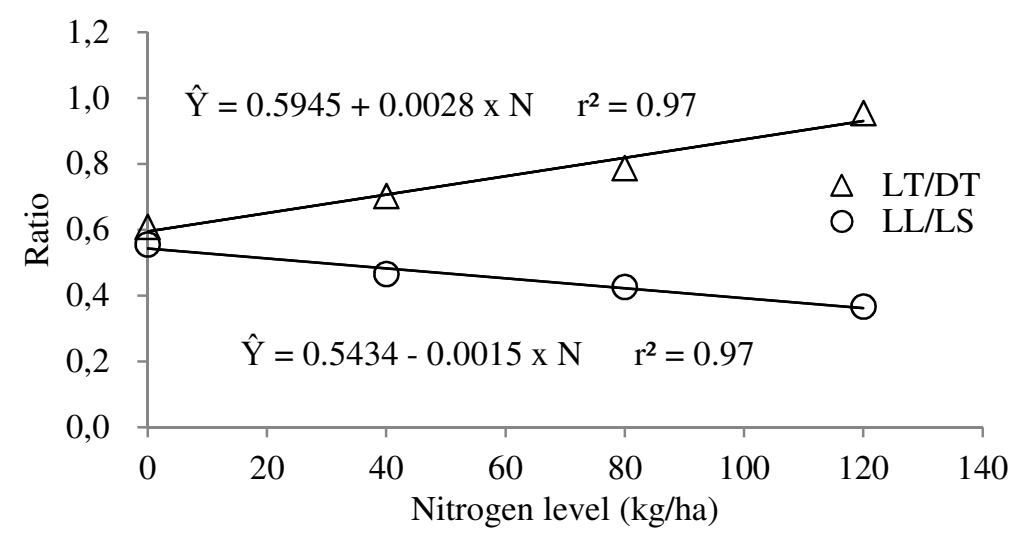

Figure 4. Ratio between the masses of live tissues and dead tissues (LT/DT) and between the masses of live leaf and live stem (LL/LS) of Signalgrass deferred and fertilized with nitrogen doses.

The number of vegetative and live tillers increased linearly $(\mathrm{P}<0.05)$ with increase in the nitrogen dose (Figure 5). However, the number of vegetative and dead tillers did not vary with the nitrogen dose $(\mathrm{P}>0.05)$. 


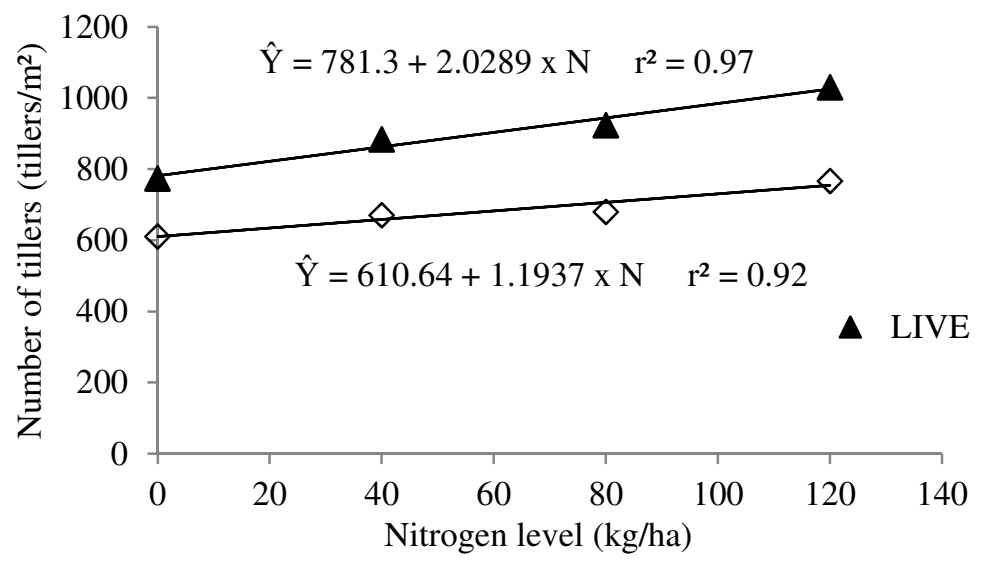

Figure 5. Number of vegetative (VEG) and live (LIVE) tillers of Signalgrass deferred and fertilized with nitrogen doses.

\section{DISCUSSION}

The Signalgrass deferred at high initial height presented greater amount of tillers at a more advanced development than that deferred at a lower initial height (Table 3). These older tillers grew under a more shaded environment, which stimulates stem elongation in an attempt to obtain more light (Da SILVA; NASCIMENTO JÚNIOR, 2007). Moreover, part of these older tillers also presented greater stem elongation due to the change from the vegetative to the reproductive stage. This way, the larger size of tillers on the Signalgrass deferred at higher initial heights determined superior plant and extended plant heights (Table 3).

On Signalgrass, extended plant height is always longer than plant height, due to the structural characteristic of this grass, which presents decumbent growth, slender and flexible stem. Thus, even without fallen tillers, Signalgrass presents falling rate higher than 1.0. The falling rate allows a better analysis of the effect of variations in plant and extended plant heights on the pasture lodging degree (SANTOS et al., 2009a). On pastures with elevated lodging, there are signs of occurrence of greater potential of losses of forage, which, when not consumed, will not be converted to animal product, which results in inefficiency of the productive system. In general, falling rate values below or equal to 1.5 characterize a pasture without lodging; values between 1.5 and 2.0 classify the pasture as moderately lodged; values superior to 2.0 characterize very lodged pastures (SANTOS et al., 2007). In this study, the elevation in the initial sward height increased the falling rate of Signalgrass (Table 3). However, one can consider that there was no significant lodging of plants, for the falling rate values were $1.16 ; 1.25$; and 1.55 for the Signalgrass deferred at low, medium and high initial heights, respectively.
It is worth remarking that the falling rate values were low probably because the evaluations occurred without the presence of animals grazing. These animals increase plant falling (SANTOS et al., 2009a) due to their moving around the area, which alters the structure of the deferred pasture. This happens more markedly on pastures with greater height at the beginning of the period of pasture utilization. In this context, one can infer that, even with the low falling rate, the Signalgrass deferred at greater initial heights tends to be more susceptible to falling when under grazing.

The forage mass was greater in the Signalgrass deferred at medium and high initial heights (Table 3). More lenient cuts remove smaller quantity of forage, which results in larger remaining leaf area at the beginning of regrowth (Sousa et al., 2012). Thus, the greater forage mass at the end of the deferment period is partly due to the greater mass at the beginning of deferment. Besides, in this condition, there is more competition for light, which results in accented elongation of the stem so as to expose the new leaves at the upper part of the sward (DA SILVA; NASCIMENTO JÚNIOR, 2007). In this process, there is shading of the lower leaves and smaller tillers, which tend to die, contributing to greater masses of live stem, dead stem and dead leaf (Table 3).

The more shading of the sward of Signalgrass deferred at greater heights (20 and 30 $\mathrm{cm}$ ) can be inferred from the study conducted by Portela et al. (2011). The authors evaluated Signalgrass managed under continuous stocking and verified that above $20 \mathrm{~cm}$ of height, pastures intercepted more than $95 \%$ of the incoming light. Therefore, from $20 \mathrm{~cm}$ on, the Signalgrass presented elevated competition for light between the tillers. In such condition, most photoassimilates are reallocated for the growth of existing tillers rather than new tillers (PEDREIRA et al., 2001), which 
might have inhibited the appearance of vegetative tillers (Table 3).

It is also likely that the permanence of more remaining mass in the Signalgrasses deferred at medium and high initial heights made their regrowth occur from older tissues, which would also explain the greater senescent forage mass (dead leaves and stems) after the deferment period. Conditions of more forage removal (low initial height) enable greater penetration of light inside the sward (Sousa et al., 2012), making regrowth possibly occur from new vegetative tillers (Table 3 ), which could explain its smaller masses of live stem, dead stem and dead leaf. According to Langer (1963), higher light intensities favored tillering. In addition, the Signalgrass deferred at low initial height presented smaller forage mass, but higher percentages of live leaves and live leaf/live stem ratio than that deferred at medium and high initial heights (Table 3). Such compensation resulted in a similar mass of live leaf between the initial heights assessed, whose average was $1,173 \mathrm{~kg} / \mathrm{ha} \mathrm{DM}$.

It is possible that, on the Signalgrass deferred at a low initial height, most of the apical meristems of the bigger tillers and under more advanced development were eliminated during the cutting which happened at the beginning of deferment. Therefore, it is possible that the regrowth during the deferment period occurred from younger tillers, which had not yet reached the point of floral differentiation. This explains the smaller number of reproductive tillers on the Signalgrass deferred at low initial height, in comparison with that deferred at medium and high heights (Table 3 ). On the other hand, on the Signalgrass deferred at higher initial heights, regrowth might have occurred from older tillers, which did not have their apical meristem eliminated by the cutting. Thus, as a sequence of the natural cycle of the plant, these tillers reached reproductive stage during the deferment period. According to Santos e Bernardi (2005), climatic conditions unfavorable to growth, especially by reduction of water availability in the soil and photoperiod during the period of deferment, contribute to greater number of reproductive tillers.

It was already expected that elevation in the dose of nitrogen would increase plant and extended plant heights, once this nutrient stimulates the growth of grasses (DURU; DUCROCQ, 2000; Fagundes et al., 2006), by means of greater cell division and elongation (TAIZ; ZEIGER, 2009). However, it is possible that the long period in which the Signalgrass remained deferred (118 days) caused plants to be in an advanced development stage, which annulated the effect of nitrogen on the size of tillers and, consequently on the height of the extended plant. In this sense, the falling rate, which is obtained by the division of extended plant height by plant height, was not affected by nitrogen fertilization either $(\mathrm{P}>0.05)$.

The effect of nitrogen on the increase of forage production on pastures is partly attributed to stimulation to grass tillering (MAZZANTI et al., 1994; MARUSCELLO et al., 3005; 2006), which increase the number of vegetative tillers. According to da Silva et al. (2008), nitrogen fertilization affects leaf elongation and tillering rate, for promoting greater capacity of formation of axillary buds, which may potentially originate new tillers. However, with augmentation in the leaf area index on fertilized pastures, there is more shading of smaller leaves and tillers, which can end up dying (SBRISSIA et al., 2010). This fact could explain the increase in the masses of dead morphological components (leaf and stem) of Signalgrass under larger doses of nitrogen, in relation to that deferred with smaller doses (Figure 1).

The greater number of vegetative tillers on the Signalgrass deferred with higher doses of nitrogen is corroborated by the results of Morais et al. (2006), who report that nitrogen fertilization (from 75 to $300 \mathrm{~kg} /$ ha.year of nitrogen) increased the number of vegetative tillers due to the positive effect of nitrogen on the site filling, which is the relation between the appearance of tillers on pasture and the emergence of new leaves on the tiller. The number of leaves formed determines the potential rate of tiller appearance, once there is a vegetative bud on each leaf axil (NELSON, 2000). Morais et al. (2006) also reported that the number of dead tillers remained relatively constant for the nitrogen doses applied to the same height.

The response pattern of the number of tillers was mostly a result of the increase in the number of vegetative tillers, since there was no significant increase in the number of reproductive tillers in function of nitrogen dose. These results differ from those found by Santos et al. (2009b), in which nitrogen fertilization did not change the number of vegetative tillers on pastures deferred for 116 days. It is likely that the different results are due to the association between nitrogen and the climatic conditions (MORAIS et al., 2006). According to Langer (1963), tillering is stimulated mainly by temperature, availability of water and nutrients, especially nitrogen. The efficiency of absorption and use of nitrogen by the plant is affected by the conditions of the environment at the time and place at which the evaluation takes place. 
Live stem mass was the variable that most contributed to the increase in total forage mass with the application of nitrogen. In fact, the slope of the regression equation of live stem mass was: 2.9 times higher than that of dead stem mass; 3.9 times higher than that of dead leaf mass; and 4.03 times superior to that of live leaf mass (Figures 1 and 2). This explains the positive and linear effect of the nitrogen dose on the percentage of live stems (Figure 2).

The greater occurrence of vegetative tillers on the Signalgrass fertilized with nitrogen (Figure 5) can explain the higher live tissue/dead tissue ratio (Figure 4). Vegetative tillers are usually younger than reproductive ones, so the former present more relative participation of live leaves and stems, and inferior percentage of dead leaves, when compared with reproductive tillers (Santos et al., 2009a). There is evidence that the age group of tillers has an influence on the morphogenetic and structural characteristics, resulting in progressive loss of vigor with advance in tiller age (MONTAGNER et al., 2011; PAIVA et al., 2011). Thus, management practices that foster quick tiller renewal are desirable, once new tillers present higher growth rates than old tillers.

Although nitrogen increased the mass of live tissues/dead tissues on the deferred Signalgrass (Figure 4), one can observe that, at the same time, the ratio between the masses of live leaf/live stem decreased linearly with nitrogen fertilization (Figure 4). This indicates that a big part of the live tissues present on the Signalgrass was comprised of stem (Figures 2 and 3). This pattern can interfere with animal intake and performance. According to Da Silva et al. (2008), the maximum voluntary intake by animals occurs when there is high percentage of accessible leaves - but must be emphasized that the stem and the dead tissue may limit intake, even if the forage availability is high. In addition to presenting lower nutritional value in relation to the leaf (VAN SOEST, 1994), the stem can restrict forage intake by the animal for being a physical barrier to defoliation, reducing the facility of forage harvesting by the grazing animal (CARVALHO et al., 2005) and the utilization of pastures (CARNEVALLI et al., 2006).

However, Santos (2007), working with crossbred male cattle originally intended to dairy production, with access to the concentrate supplement, on deferred pastures, reported that the morphological component live stem would not necessarily be a hindrance to defoliation in this model of pasture management, especially in the case of forage plants which have slender stems, such as Brachiaria decumbens. In the same study, the author found similar positive correlations between daily weight gain and masses of forage and live leaf, which, in turn, were higher than the correlation found between daily weight gain and forage mass.

Thus, when performing pasture deferment, it is expected that there be adequate forage accumulation, which will allow the maintenance of animals on pasture during the period in which the climatic conditions are adverse to the growth of the forage plant (FONSECA; SANTOS, 2009). However, it is necessary to consider that the nutritional value of forage plants of tropical climate decreases with accumulation in the forage mass. So, excessive forage accumulation can drastically affect the nutritional aspect. Besides, higher Signalgrass pastures, especially when subjected to grazing, present better lodging potential (Santos et al., 2009a), negatively affecting selectivity (Santos et al., 2011), the ingestive behavior of animals and pasture utilization (CARNEVALLI et al., 2006; TRINDADE et al., 2007).

In addition to forage mass, it is also relevant to observe the structural characteristics of the deferred pasture, in order to recommend more adequate management strategies (Fonseca $\&$ Santos, 2009). Thus, in spite of the elevated forage mass, the Signalgrass deferred at high initial height, especially the one which received greater doses of nitrogen, presented greater falling rate, which is undesirable. Lodging, which can be aggravated by grazing, negatively interferes with the ingestion of forage by animals and promotes increase in the forage losses (SANTOS et al., 2009c). Furthermore, the Signalgrass deferred at high initial height also presented greater percentage of dead stem (Figure 3) and lower live leaf mass/live stem mass ratio (Figure 4).

\section{CONCLUSIONS}

Nitrogen fertilization and the initial height of the sward result, in general, in effects of the same nature on the forage mass of the deferred Signalgrass.

The Signalgrass deferred at low and medium initial heights presents adequate structure, characterized by lower plant lodging and higher live leaf/live stem ratio. This grass can be deferred at low and medium initial heights and varied nitrogen doses, according to the objectives and possibilities of the farmers. 
RESUMO: Este estudo foi realizado com o objetivo de avaliar as características e produção de forragem de capim braquiária (Brachiaria decumbens cv. Basilisk) diferida sob diferentes alturas iniciais e doses de nitrogênio. Três alturas iniciais do pasto (baixo $-10 \mathrm{~cm}$, médio $-20 \mathrm{~cm}$ e alto $-30 \mathrm{~cm}$ ), três doses de nitrogênio $(40,80 \mathrm{e} 120 \mathrm{~kg} / \mathrm{ha})$ e um tratamento controle, sem adubação, foram avaliados. O delineamento experimental utilizado foi o de blocos completamente casualizados com três repetições em esquema de parcelas subdivididas. Não houve interação entre altura inicial do pasto e dose de nitrogênio para as variáveis analisadas. O capim-braquiária diferido com maior altura inicial do dossel apresentou maiores massas de forragem, de colmo vivo, de colmo morto e de folha morta, número de perfilhos reprodutivos, porcentagem de colmo morto e índice de tombamento, bem como menor número de perfilhos vegetativos, porcentagem de folha viva, relação folha viva/colmo vivo. A elevação na dose de nitrogênio aumentou o número de perfilhos vivos e vegetativos, a massa de forragem, de colmo vivo, de colmo morto, de folha morta e de folha viva, a porcentagem de colmo vivo, a relação tecidos vivos/tecidos mortos e diminuiu a porcentagem de folhas mortas e a relação folha viva/colmo vivo. O capim-braquiária pode ser diferido com altura inicial baixa e média e doses de nitrogênio variadas, de acordo com os objetivos e possibilidades do pecuarista.

PALAVRAS-CHAVE: Brachiaria decumbens. Estacionalidade de produção. Estrutura do dossel. Perfilhamento

\section{REFERENCES}

CANTARUTTI, R. B.; MARTINS, C. E.; CARVALHO, M. M. et al. Pastagens. In: RIBEIRO, A. C.; GUIMARÃES, P. T. G.; ALVAREZ VENEGAS, V. H. Recomendações para o uso de corretivos e fertilizantes em Minas Gerais ( $5^{\mathbf{a}}$ Aproximação). Viçosa: Comissão de Fertilidade do Solo do Estado de Minas Gerais, 1999. p. 332-341.

CARNEVALLI, R. A.; SILVA, S. C.; BUENO, A. A. O. et al. Herbage production and grazing losses in Panicum maximum cv. Mombaça under four grazing managements. Tropical Grasslands, Cali, v. 40, p. 165176, 2006.

CARVALHO, P. C. F.; GENRO, T. C. M.; GONÇALVES, E. N. et al. Estrutura do pasto como conceito de manejo: reflexos sobre consumo e a produtividade. In: SIMPÓSIO SOBRE VOLUMOSOS NA PRODUÇÃO DE RUMINANTES, 2., 2005, Jaboticabal. Anais... Jaboticabal: FUNEP, 2005. p. 107-124.

Da SILVA, S. C.; NASCIMENTO JÚNIOR, D. Avanços na pesquisa com plantas forrageiras tropicais em pastagens: características morfofisiológicas e manejo do pastejo. Revista Brasileira de Zootecnia, Viçosa, v. 36, n. 4, p. 121-138, 2007 (suplemento especial). http://dx.doi.org/10.1590/s1516-35982007001000014

Da SILVA, S. C.; NASCIMENTO JÚNIOR, D.; EUCLIDES, V. B. P. Pastagens: Conceitos básicos, produção e manejo. Viçosa, MG: Suprema, 2008. 115p.

DURU, M.; DUCROCQ, H. Growth and senescence of the successive grass leaves on a tiller. Ontogenic development and effect of temperature. Annals of Botany, Exeter, v. 85, p. 635-643, 2000.

http://dx.doi.org/10.1006/anbo.2000.1116 http://dx.doi.org/10.1006/anbo.1999.1117

EMPRESA BRASILEIRA DE PESQUISA AGROPECUÁRIA - EMBRAPA. Serviço Nacional de Levantamento e Conservação de Solos. Sistema brasileiro de classificação de solos. $2^{\mathrm{a}}$ ed. Rio de Janeiro: Embrapa Solos, 2006. 306p.

FAGUNDES, J.A.; FONSECA, D.M.; MORAES, R.V. et al. Avaliação das características estruturais do capim-braquiária em pastagens adubadas com nitrogênio nas quatro estações do ano. Revista Brasileira de Zootecnia. Viçosa, v.35, n.1, p.30-37, 2006. http://dx.doi.org/10.1590/S1516-35982006000100004 http://dx.doi.org/10.1590/S1516-35982006000100003 
FONSECA, D. M.; SANTOS, M. E. R. Diferimento de pastagens: Estratégias e ações de manejo. In: SIMPÓSIO DE FORRAGICULTURA E PASTAGEM, 6.; CONGRESSO DE FORRAGICULTURA E PASTAGEM, 3., 2009, Lavras. Anais... Lavras: UFLA, 2009. p.65-88.

KÖPEN, W. Climatologia. Buenos Aires: Gráfica Panamericana, 1948. 478p.

LANGER, R. H. M. Tillering in herbage grass. A review. Herbage abstracts, Wallingford, 33, p. 141-148, 1963.

MAZZANTI, A.; LEMAIRE, G.; GASTAL, F. The effect of nitrogen fertilization upon herbage production of tall fescue swards grazed by sheep. 1. Herbage growth dynamics. Grass and Forage Science, Norfolk, v. 49, p. 111-120, 1994. http://dx.doi.org/10.1111/j.1365-2494.1994.tb01983.x

http://dx.doi.org/10.1111/j.1365-2494.1994.tb02010.x

MARTUSCELLO, J. A.; FONSECA, D. M.; NASCIMENTO JÚNIOR, D. et al. Características morfogênicas e estruturais do capim-xaraés submetido à adubação nitrogenada e desfolha. Revista Brasileira de Zootecnia, Viçosa, v. 34, n. 5, p. 1475-1482, 2005. http://dx.doi.org/10.1590/S1516-35982005000500007

MARTUSCELLO, J. A.; FONSECA, D. M.; NASCIMENTO JÚNIOR, D. et al. Características morfogênicas e estruturais do capim-massai submetido à adubação nitrogenada e desfolhação. Revista Brasileira de Zootecnia, Viçosa, v. 35, n. 3, p. 665-672, 2006. http://dx.doi.org/10.1590/S1516-35982006000300006

MORAIS, R. V.; FONSECA, D. M.; NASCIMENTO JÚNIOR, D. et al. Demografia de perfilhos basilares em pastagem de Brachiaria decumbens adubada com nitrogênio. Revista Brasileira de Zootecnia, Viçosa, v. 35, n. 2, p. 380-388, 2006. http://dx.doi.org/10.1590/S1516-35982006000200007

MONTAGNER, D. B.; NASCIMENTO JÚNIOR, D.; SOUSA, B. M. L. et al. Morphogenetic and structural characteristics of tillers of Guinea grass of different age and grazing severities. Revista Brasileira de Zootecnia, Viçosa, v. 40, n. 10, p. 2105-2110, 2011. http://dx.doi.org/10.1590/S1516-35982011001000006

NELSON, C. J. Shoot Morphological plasticity of grasses: leaf growth vs. tillering. In: LEMAIRE, G. et al. (Eds.) Grassland ecophysilogy and grazing ecology. CABI, Wallingford, UK, p. 101-126, 2000. http://dx.doi.org/10.1079/9780851994529.0101

PAIVA, A. J.; SILVA, S. C.; PEREIRA, L. E. T. et al. Morphogenesis on age categories of tillers in Marandu palisadegrass. Scientia Agricola, Piracicaba, v. 68, n. 6, p. 626-631, 2011.

PORTELA, J. N.; PEDREIRA, C. G. S.; BRAGA, G. J. Demografia e densidade de perfilhos de capimbraquiária sob pastejo em lotação intermitente. Pesquisa Agropecuária Brasileira, Brasília, v. 46, n. 3, p. 315322. 2011.

SANTOS, M. E. R. Características da forragem e produção de bovinos em pastagens de capim-braquiária diferidas. 2007. 100f. Dissertação (Mestrado em Zootecnia) - Universidade Federal de Viçosa, Viçosa, MG, 2007.

SANTOS, P. M.; BERNARDI, A. C. C. Diferimento do uso de pastagens. In: SIMPÓSIO SOBRE MANEJO DA PASTAGEM, 22, 2005, Piracicaba. Anais... Piracicaba: Fundação de Estudos Agrários Luiz de Queiroz, 2005. p. 95-118.

SANTOS, M. E. R.; FONSECA, D. M.; EUCLIDES, V. P. B. et al. Características estruturais e índice de tombamento de Brachiaria decumbens cv. Basilisk em pastagens diferidas. Revista Brasileira de Zootecnia, Viçosa, v. 38, n. 4, p. 626-634, 2009c. http://dx.doi.org/10.1590/S1516-35982009000400006 
SANTOS, M.E.R.; FONSECA, D.M.; EUCLIDES, V.P.B. et al. Produção de bovinos em pastagens de capimbraquiária diferidas. Revista Brasileira de Zootecnia, Viçosa, v. 38, n. 4, p. 635-642, 2009d.

http://dx.doi.org/10.1590/S1516-35982009000400007

SANTOS, M. E. R.; FONSECA, D. M.; BALBINO, E. M. et al. Caracterização de perfilhos em pastos de capim-braquiária diferidos e adubados com nitrogênio. Revista Brasileira de Zootecnia, Viçosa, v. 38, n. 4, p. 643-649. 2009a. http://dx.doi.org/10.1590/S1516-35982009000400008

http://dx.doi.org/10.1590/S1516-35982009000400009

SANTOS, M. E. R.; FONSECA, D. M.; BALBINO, E. M. et al. Capim-braquiária diferido e adubado com nitrogênio: produção e características da forragem. Revista Brasileira de Zootecnia, Viçosa, v. 38, n. 4, p. 650-656, 2009b. http://dx.doi.org/10.1590/S1516-35982009000400008

http://dx.doi.org/10.1590/S1516-35982009000400009

SANTOS, M. E. R.; FONSECA, D. M.; EUCLIDES, V. P. B. et al. Valor nutritivo da forragem e de seus componentes morfológicos em pastagens de Brachiaria decumbens diferida. Revista Brasileira de Agropecuária Sustentável, Viçosa, v. 1, n. 1, p. 112-122, 2011.

SBRISSIA, A. F.; SILVA, S. C.; SARMENTO, D. O. L. et al. Tillering dynamics in Marandu palisadegrass swards continuously stocked by cattle. Plant Ecology, Perth, v. 206, p. 349-359, 2010.

http://dx.doi.org/10.1007/s11258-009-9647-7

SOUSA, B. M. L.; VILELA, H. H.; SANTOS, A. L. et al. Piata palisadegrass deferred in the fall: effects of initial height and nitrogen in the sward structure. Revista Brasileira de Zootecnia, Viçosa, v. 41, n. 5 , p. 1134-1139, 2012. http://dx.doi.org/10.1590/S1516-35982012000500008

TAIZ, L.; ZEIGER, E. Fisiologia Vegetal. $4^{a}$ ed.; Tradução SANTARÉM, E.R. et al. - Porto Alegre: Artmed, 848p. 2009.

TRINDADE, J. K.; SILVA, S. C.; SOUZA JÚNIOR, S. J. et al. Composição morfológica da forragem consumida por bovinos de corte durante o rebaixamento do capim-marandu submetido a estratégias de pastejo rotativo. Pesquisa Agropecuária Brasileira, Brasília, v. 42, p. 883-890, 2007.

http://dx.doi.org/10.1590/S0100-204X2007000600016 